\title{
Anti-tumor activity of some pyrazoline derivatives
}

Faten Zahran 1, Abdel Aziz, A.F.2 , Mai Hamdy

1. Professor of Biochemistry, Faculty of Science, Zagazig University, Egypt.

2. Professor of Biochemistry, Faculty of Science, Mansoura University, Egypt.

\section{ART I CLE INFO \\ Article history: \\ Received : \\ Accepted : \\ Available online : \\ Keywords: \\ Pyrazoline deivatives \\ Cancer}

Antioxidant

\begin{abstract}
A B S T R A C T
Background: Pyrazolines are heterorcycles that attracted considerable attention in the design of biologically active molecules, possess abroad spectrum of biological effective ness including anticancer activities act as alkaylating agents in the chemotherapy of cancer., Changes instructureof pyrazoline derivatives offered a high degree of diversity as they are useful for the development of new therapeutic agents improved in potency and lesser toxicity, Aim: The main objective of the present study is to evaluate the chemotherapeutic effects of some novel substituted pyrazoline compounds against animal carcinogesis.

Materials \& Methods: The synthesized pyrazoline derivatives were characterized by IR spectroscopy, and then their effects on Ehrlich Carcinoma were studied by evaluation their antitumor activity (viability of tumor cells, and life span prolongation), and estimation of (Malondialdehyde ,Nitric oxide, Total antioxidant capacity levels and activities of Superoxide Dismutase , and Arginase) Results: Pyrazoline derivatives showed a significant reduction in the volume and count of Ehrlich cells. Also,they suggested potential antioxidant activity by elevation superoxide dismutase, Total Antioxidant capacity, and reduction of Malondialdehyde, Nitric oxide, and Arginase. Conclusion: The activities of synthesized pyrazoline compounds have potent antitumor, antioxidant, and decrease the survival of cancer cells.

(c) 2016 Publisher All rights reserved.
\end{abstract}

\section{INTRODUCTION}

; 80: 1713-1720.

Cancer is not a single disease, but act as agroup of diseases which characterized by uncontrolled, rapid, and pathological proliferation of abnormal cells. cancer is an important cause of death after cardiovascular disorders around the world although recent advances studies in cancer therapy ${ }^{(1)}$.
Chemotherapeutic agents are A challenge in the fight against cancer. Another challenge for chemotherapy is lack of selectivity. as anticancer drugs destroy normal cells as well as cancer cells and may affected adversely. New antineoplastic agents are developed continously to be selectively destroy tumor cells or at least limit their proliferation. ${ }^{(2)}$ 
Pyrazolines are important nitrogen containing five membered heterocyclic bioorganic molecules These compounds occured in nature as alkaloids, vitamins, and pigment sand as plant and animal cell contents (3). Activity of pyrazolines differed due to avariety of functional groups as substituents and widely used due to their various biological and pharmacological activities in the current decades ${ }^{(4)}$.pyrazolines are not only useful in treatment of various cancer types ,but also some of them act as cancer chemopreventive agents. ${ }^{(5)}$

C5 atom deviated from planar system of the other four atoms of the heterocyclic ring ${ }^{(6)}$.

2-pyrazoline is insoluble in water but soluble in propylene glycol or DMSO(dimethyl sulfoxide) because of its lipophilic character (7). Pyrazoline derivatives are Intra-molecular Charge Transfer (ICT) compounds, an intramolecular conjugated charge transfer process reported to exist it in the excited state. In the conjugated part $(-\mathrm{N} 1-\mathrm{N} 2-\mathrm{C} 3-)$ of the ring, the nitrogen atom at the 1-position is electron donating and the carbon atom at the 3position has withdrawing activity, but The carbon atoms at 4-and 5-positions do not conjugate with the above conjugated part ${ }^{(\mathbf{8})}$.

2-Pyrazolines is the most pyrazoline type that used widely ${ }^{(\boldsymbol{9 )}}$. The popular procedure is based on the reaction of $\alpha, \beta$ un saturated aldehydes and ketones with hydrazines (10). The combination of the hydrazono group with other functional groups leads pyrazoline compounds to be unparalleled in physical and chemical properties. Pyrazoline derivatives display various biological activities such as antitumor, antifungal, antiviral, anti- parasitic ,anti-inflammatory, analgesic, antimycobacterial , anticancer, antibacterial,

insecticidal, antinociceptive, hypotensive ,anti- depressant, photoluminiscence, antitubercular, anti-amoebic, amine oxidase inhibitory and antioxidant properties ${ }^{(11)}$. In our study antioxidant enzyme observed as they are native to normal tissue or they associated with changes in metabolism and that are unique to cancer tissue.

Nitric oxide (NO) is the simplest active molecule which synthesized from L- arginine amino acid by the enzyme nitric oxide synthase (NOS). It is the only endogenous molecule acts as a mediator, a hormone ,a reactive Oxygen species (ROS), neurotransmitter, cytoprotective and cytotoxic molecule ${ }^{(\mathbf{1 2})}$. A decrease in NO production stimulates oxidative phosphorylation and

increases peripheral oxygen uptake ${ }^{(\mathbf{1 3})}$ that caused by lipid peroxidation, nitrosylation of molecules, in activation of sodium channels, and redox reaction with metals such as iron and copper (14) Arginase (L - arginine amidino hydrolase) is

homotrimeric metalloenzyme that catalyzes the hydrolysis of L-arginine, execution urea for ammonia elimination, and L-ornithine (a non-protein amino acid), for biosynthetic pathways ${ }^{(15)}$ there are two forms of arginase.

1) Arginase $I$ is cytosolic ,it almost found in the liver, responsible for ammonia detoxification as urea,2)Arginase II, is isoenzyme which involved in the production of ornithine as a precursor essential for cellular growth ${ }^{(16)}$. Polyamines are important for cell proliferation as the increased level of ornithine, due to the elevated arginase activity, refered to the development of carcinogenesis ${ }^{(\mathbf{1 7})}$.

Ahigh arginase level in breast cancer was detected to be released into serum . Arginase enzyme is a useful biological marker in breast cancer and act as an indicator of breast cancer progression, the more advanced the breast cancer, the higher the serum level of arginase enzyme activity, The activity levels of arginase in malignant breast tissues were reported by Porembska et al. ${ }^{(\mathbf{1 8})}$; Straus et al. ${ }^{(\mathbf{1 9})}$ and Erbas etal. ${ }^{(20)}$.The relationship between the $\mathrm{NO}$ and arginase involves not only the use of the same substrate ${ }^{(\mathbf{2 1})} ;{ }^{(22)}$ but also, In healthy individuals, sufficient arginase activity can limit the use of arginine for the synthesis of $\mathrm{NO}^{(\mathbf{2 3})(\mathbf{2 4})}$.

This work aims to investigate the antitumor and antioxidant activities of some pyrazoline derivatives.

Materials and Methods: Synthesis of Pyrazolines 
Pyrazoline derivatives were synthesized ${ }^{(25)}$ As The chalcones were condensed with phenyl hydrazine in absolute ethanol in the presence of pyridine at reflux temperature ( 2 to $6 \mathrm{~h}$ ). The solvent was completely evaporated and the residue was poured into ice cold water, which resulted in the formation of the corresponding 2-pyrazolines. Reaction completion was identified by thin layer chromatography (TLC) using silica gelG. After completion of the reaction, the reaction mixture was poured into crushed ice with constant stirring. The separated solid was filtered and dried. It was purified by column chromatography on silica gel, using ethyl acetate and hexane mixture as the mobile phase. After purification the 2pyrazolines were obtained as light or bright colored powders.

Elucidation of Chemical structure of Pyrazoline derivatives:

Compound (1):1-Phenyl-3-methyl-4-(ochloro phenyl (azo) hydrazono)-2-pyrazoline5-one ,compound (2):1-Phenyl-3-methyl-4(m-chloro phenyl (azo)hydrazono)-2pyrazoline-5-one ,compound (3):1-Phenyl3methyl-4-(m-nitro phenyl (azo)hydrazono)2-pyrazoline-5-one, compound (4):1-Phenyl3- methyl-4-(o-methyl phenyl (azo)hydrazono)-2-pyrazoline -5-one,

And Compound (5): 1-Phenyl-3-methyl-4(m-

methoxy phenyl(azo)hydrazono)-2pyrazoline-5-one, were identified using IR according to Laurence and Christopher method $^{(\mathbf{2 6})}$.The structure of the synthesized compounds illustrated in fig. (1, 2,3,4,and 5) .

\section{Animals}

Adult female Swiss albino mice weigh (20-25 g) were purchased Abo Rawash culture Giza used throughout this study. The animals were housed in steel mesh cages (animal house, faculty of Science, Zagazig University) and maintained in controlled environment of temperature, humidity, light, and fed on a commercial standard diet and tap water ad libitum.

\section{Ehrlich ascites carcinoma (EAC)}

EAC cells were initially supplied from the National Cancer Institute, Cairo, Egypt (only for the first transplantation), and maintained in female Swiss albino mice through serial intraperitoneal (I.P.) as the dose was $0.064 \mathrm{ml}$ of EAC complete till $0.3 \mathrm{ml}$ with saline that containing $\left(2.5 \times 10^{6}\right.$ cells $)$ inoculation at 8 or 10 day intervals in our laboratory in an ascites form.

\section{Toxicity Study}

Determination median lethal dose (LD 50) of the synthesized compounds: Approximate LD50 of albino Swiss mice was determined according to method Meier and Theakston, (1986) ${ }^{(27)}$. The acute toxicity was estimated by intraperitoneal injection of the compounds $(1,2,3,4$, and 5$)$ to determine the median lethal dose (LD50) of each compound.

\section{Experimental design}

Female Swiss albino mice were divided into the following groups (10 mice/ each group) as follows: Group (I): Negative Control: mice injected I.P. with sterile saline for 10 days. Group (II): Positive Control (EAC bearing group): mice injected I.P. with EAC cells, $\left(2.5 \times 10^{6}\right.$ cells $/ 0.3 \mathrm{ml}$ per mouse) once. Group (III) treated group with compound 1: was subdivided into the following three subgroups: (a): Therapeutic Group: (EAC+ compound 1) : mice were injected I.P. with compound $1(200 \mathrm{mg} / \mathrm{Kg})$ after EAC injection $\left(2.5 \times 10^{6}\right.$ cells /mouse), followed by I.P. injection of compound 1 at 3, 5, 7, 9 days of EAC injection for 10 days. $(b)$ : Preventive Group: (compound 1 + EAC): mice were injected I.P. with compound $1(200 \mathrm{mg} / \mathrm{Kg})$ day before EAC injection $\left(2 \times 10^{6}\right.$ cells/mouse), followed by I.P. injection of compound 1 at 3, 5, 7, 9 days of EAC injection for10 days.(c):Positive Drug 1 Group:(compound 1): mice were injected I.P. with compound $1(200 \mathrm{mg} / \mathrm{Kg})$ day after day for 10 days. Group (IV) compound (2) treated group: was subdivided into the following three subgroups: (a): Therapeutic Group: (EAC + compound 2): mice were injected I.P. with compound $2(200 \mathrm{mg} / \mathrm{Kg})$ after EAC injection $\left(2.5 \times 10^{6}\right.$ cells/ mouse $)$, followed by I.P. injection of compound 2 at 3, 5, 7, 9 days of EAC injection for 10 days. (b): Preventive Group: (compound 2+ EAC): mice were injected I.P. with compound 2 (200 mg/Kg) 
day before EAC injection $\left(2.5 \times 10^{6}\right.$ cells/mouse), followed by I.P. injection of compound 2 at 3, 5, 7, 9 days of EAC injection for 10 days. (c): Positive Drug 2 Group: (compound 2): mice were injected I.P. with compound $2(200 \mathrm{mg} / \mathrm{Kg})$ day after day for 10 days. Group (V) compound (3) treated group: mice were injected I.P. with compound 3 was subdivided into the following three subgroups: (a): Therapeutic Group: (EAC + compound 3): mice were injected I.P. with compound $3(200 \mathrm{mg} / \mathrm{Kg})$ after EAC injection $\left(2.5 \times 10^{6}\right.$ cells / mouse $)$, followed by I.P. injection of compound 3 at 3 , 5, 7, 9 days of EAC injection for 10 days. $(b)$ : Preventive Group: (compound 3+EAC) mice were injected I.P. with compound 3 (200 $\mathrm{mg} / \mathrm{Kg})$ day before EAC injection $\left(2.5 \times 10^{6}\right.$ cells/mouse), followed by I.P. injection of compound 3 at $3,5,7,9$ days of EAC injection for 10 days. (c): Positive Drug 3 Group: (compound 3): mice were injected I.P. with compound $2(200 \mathrm{mg} / \mathrm{Kg})$ day after day for 10 days. Group (VI) compound (4) treated group: was subdivided into the following three subgroups: (a) Therapeutic Group: (EAC + compound 4): mice were injected I.P. with compound $4(200 \mathrm{mg} / \mathrm{Kg})$ after EAC injection $\left(2.5 \times 10^{6}\right.$ cells/mouse), followed by I.P. injection of compound 4 at 3 , 5, 7, 9 days of EAC injection for 10 days. (b) Preventive Group: (compound 4+EAC) mice were injected I.P. with compound 4 (200 $\mathrm{mg} / \mathrm{Kg})$ day before EAC injection $\left(2.5 \times 10^{6}\right.$ cells/mouse), followed by I.P. injection of compound 4 at 3, 5, 7, 9 days of EAC injection for 10 days. (c): Positive Drug 4 Group: (compound 4): mice were injected I.P. with compound $4(200 \mathrm{mg} / \mathrm{Kg})$ day after day for 10 days. Group (VII) compound (5) treated group: was subdivided into the following three subgroups:(a) Therapeutic Group: (EAC + compound 5): mice were injected I.P. with compound $5(200 \mathrm{mg} / \mathrm{Kg})$ after EAC injection $\left(2.5 \times 10^{6}\right.$ cells/mouse $)$, followed by I.P. injection of compound 5 at 3 , 5, 7, 9 days of EAC injection for 10 days; $(b)$ Preventive Group: (compound 5+ EAC): mice were injected I.P. with compound 5 $(200 \mathrm{mg} / \mathrm{Kg}$ ) day before EAC injection $\left(2.5 \times 10^{6}\right.$ cells/mouse), followed by I.P. injection of compound 5 at 3, 5, 7, 9 days of EAC injection for 10 days. (c): Positive Drug 5 Group: (compound 5) mice were injected I.P. with compound $5(200 \mathrm{mg} / \mathrm{Kg})$ day after day for 10 days.

\section{Collection of Blood Samples and EAC Cells:} at the end of the experiment, the blood samples were collected from the retro-orbital venous plexus under light ether anesthesia. Plasma prepared and stored at $-20{ }^{\circ} \mathrm{C}$ until biochemical analysis. EAC cells were harvest from each mouse in centrifuge tube containing heparinized saline. Note the volume of ascetic fluid in each mouse in each group. Each sample of cells were undergoes counting and viability of EAC cells in each group.

\section{Viability and Counting of EAC cells:}

The viability of EAC cells was determined by the Trypan Blue Exclusion Method described by Mcliman etal (1957) ${ }^{(28)}$.

Effect of compounds (1, 2, 3, 4, and 5) on life span prolongation: Life span calculation was carried out according to the method described by Mazumdar etal (1997) ${ }^{(29)}$.

\section{Antioxidant assays:}

Malondialdehyde (MDA) determined according to methods of (Satoh, 1978) ${ }^{(30)}$, Nitric Oxide (NO) levels according to Montgomery and Dymock (1961) (31), Superoxide dismutase (SOD) according to Nishikimi etal ,(1972) ${ }^{(32)}$,Total Antioxidant Capacity (TAC) according to Koracevic etal.,(2010) ${ }^{(\mathbf{3 3})}$ and Arginase activities according to Marsch, etal.,(1965). ${ }^{(34)}$

\section{Statistical Analysis:}

all statistical analyses were done by a statistical for social science package "SPSS" 14.0 for Microsoft Windows, SPSS Inc. Levesque (2007) (35) and considered statistically significant at a two

sided $\mathrm{P}<0.05$.

\section{Results}

\section{Toxicity Study}

Studies carried out for determination of the median lethal dose are important to help us to assess the limit dose recommended, we use 
procedure described by to calculate the (LD 50),

Doses for all compounds were being safe until $400 \mathrm{mg} / \mathrm{kg}$; as the selective dose for all compounds were $200 \mathrm{mg} / \mathrm{kg}$, as reported by Kalpana D. (2014) ${ }^{(36)}$.

\section{Infrared spectral study:}

Fig. (1, 2, 3, 4 and 5), illustrated IR spectra of compounds (1, 2, 3, 4 and 5; respectively). In compound (1) the absorption bands at 1252,3447 and1496 for $\mathrm{OCH}_{3}, \mathrm{NH}$ and $\mathrm{N}=\mathrm{N}$ respectively. $\mathrm{N}=\mathrm{C}, \mathrm{C}-\mathrm{O}$ and $\mathrm{C}=\mathrm{O}$ groups give bands at 2366, 1152 and 1655 . C-H aromatic and $\mathrm{CH}_{3}$ aliphatic appear at 3030 and 2922. The characteristic bands of compound (1) were still present in compounds (2 to 5) except the disappear of band character of $\mathrm{OCH}_{3}$ at 1252 , and showed three new peaks at $1556,1072,1047$ attributed to $\mathrm{NO}_{2}, \mathrm{Cl}$ in meta position and $\mathrm{Cl}$ at ortho positions respectively.

\section{Viability and life span prolongation}

The mean values of EAC volume and count were found to be $5.8 \pm 0.24(\mathrm{ml})$ and $188.7 \pm$ $4.63\left(\times 10^{6}\right.$ cells $\left./ \mathrm{ml}\right)$ in EAC bearing tumor group reported by Freitas et al., (2006) ${ }^{(37)}$, Amr (1986) ${ }^{(38)}$.While, cpd1, cpd2, cpd3 ,cpd4 and cpd5 treated groups were demonstrated a significant decrease in EAC volume as in

(a) preventive groups of synthesized compounds $(1,2,3,4$, and 5) to $1.5 \pm 0.12$, No EAC, $4.3 \pm 0.12,3.4 \pm 0.13$ and $1.5 \pm 0.14$ by $74.2 \%$, No EAC, $35.9 \%, 48.43 \%$ and $65.5 \%$, respectively. (b)Therapeutic groups of synthesized

Compounds (1, 2,3,4, and 5) 2.4 \pm 0.11 , $0.7 \pm 0.09, \quad 4.8 \pm 0.126,3.8 \pm 0.13$ and $2.7 \pm 0.166$ by $57.7 \%, 87.19 \%, 15.7 \%, 33.3 \%$ and $52.63 \%$, respectively.

There was significant reduction in EAC cells count as in

(a) Preventive groups of synthesized compounds (1, 2, 3, 4, and 5): to 40.8 \pm 1.18 , No EAC, 120.9 $\pm 1.8,97.3 \pm 1.78$, and $65.07 \pm 2.4$ by $78.29 \%$,NoEAC, $35.9 \%$, $48.43 \%$, \& $65.5 \%$ respectively;

(b)Therapeutic groups of synthesizedcompounds (1, 2, 3, 4, and 5) $61.28 \pm 1.76 \quad, 23.6 \pm 0.95,140.3 \pm 2.9$,
$105.4 \pm 1.95$ and $86.29 \pm 1.42$ by $67.5 \%$, $87.44 \%, 25.6 \%, \quad 44.14 \%$ and $54.27 \%$,respectively compared to positive control group (EAC bearing tumor), ( $\mathrm{p}<0.001)$, Table (1).

The mean life span in the positive control group was found to be 16 days. cpd1, cpd2, cpd3, cpd4 and cpd5 treated groups showed a significant increase in the life span prolongation to 23 days by $44 \%$ ( $\mathrm{T} / \mathrm{C}$ ratio= 144\%), 29 days by $81 \%$ (T/C ratio $=181 \%$ ), 21 days by $31 \%(\mathrm{~T} / \mathrm{C}$ ratio $=131 \%), 25$ days by $56 \%(\mathrm{~T} / \mathrm{C}$ ratio $=156 \%)$ and 26 days by $63 \%(\mathrm{~T} / \mathrm{C}$ ratio $=163 \%)$ respectively compared to the positive control group

The Increase in life span $=(\mathrm{T}-\mathrm{C}) / \mathrm{C} \times 100$ $\mathrm{T}=$ number of days the treated animals survived

$\mathrm{C}=$ number of days the control animals survived.

[T/ C Ratio = Mean survival time of treated / Mean survival time of control $\times 100$ ] table (2).

\section{Antioxidant assay:}

SOD activities, TAC levels were found to be reduced significantly from $203.8 \pm 3.87(\mathrm{U} / \mathrm{mL})$ and $0.391 \pm 0.059(\mathrm{mM} / \mathrm{L})$ Diab et al., (2012) ${ }^{(39)}$ to $98.78 \pm 4.05(\mathrm{U} / \mathrm{mL})$, and 0.198 $\pm 0.041(\mathrm{mM} / \mathrm{L})$ in EAC bearing tumor group by $106.3 \%$, and $97.47 \%$, respectively, ( $\mathrm{p}<0.001$ ), but MDA ,NO and Arginase levels were found to be increased from11.6 \pm 0.73 $(\mathrm{nmol} / \mathrm{ml})$, in negative control group Hayat, (2001) $^{(\mathbf{4 0})}$ to $42.74 \pm 1.89 \quad(\mathrm{nmol} / \mathrm{ml})$, $72.6 \%$,NO from $21.4 \pm 2.13(\mu \mathrm{mol} / \mathrm{l})$ to $51.3 \pm 3.9(\mu \mathrm{mol} / 1)$ by and $58.34 \%$, Arginase from $91.28 \pm 8.02$ (U /L) in negative control group Lindsay, (2015) ${ }^{(\mathbf{4 1})}$ to 254.5 $\pm 21.3(\mathrm{U} / \mathrm{L})$ by64.1\%, $(\mathrm{p}<0.001)$.

Meanwhile, in cpd1, cpd2, cpd3, cpd4 and cpd5 treated groups (SOD, TAC) activities were significantly increased compared to positive control group(EAC group) :

(a)Preventive group of synthesized compounds $(1,2,3,4$, and 5) to $(648.49 \pm 39.9 \quad(\mathrm{U} / \mathrm{mL})$ and $3.49 \pm 0.292$ (mM/L),by $\quad(556.4 \% \quad$ and $1662.6 \%)$ inCompound1, $(916.4 \pm 38.54(\mathrm{U} / \mathrm{mL})$ and $4.7 \pm 0$. $429(\mathrm{mM} / \mathrm{L})$, by $(827 \%$ and $2273 \%$ in compound 2, $(231.3 \pm 31.89(\mathrm{U} / \mathrm{mL})$ and 0.193 
$\pm 0.021(\mathrm{mM} / \mathrm{L})$,by $(134.13 \%$ and $2.5 \%)$ in Compound3,(391.71

20.41(U/mL) and $(0.98 \pm 0.10 \quad(\mathrm{mM} / \mathrm{L}), \quad$ by $(296.5 \%$ and $394.9 \%)$ in compound $4,(577.7 \pm 34.95(\mathrm{U} / \mathrm{mL}) \quad$ and $\quad 2.19 \pm$ $0.179(\mathrm{mM} / \mathrm{L}) \mathrm{by}(484.7 \%$ and $960.6 \%)$ in compound 5, $(\mathrm{p}<0.001)$.

(b)Therapeutic groups of synthesized compounds $(\mathbf{1}, \mathbf{2}, \mathbf{3}, \mathbf{4}$, and 5$)$ to $(516.35 \pm 40.85 \quad(\mathrm{U} / \mathrm{mL})$ and $2.62 \pm 0.22$ $(\mathrm{mM} / \mathrm{L})$, by $(422.7 \%$ and $1223.2 \%)$ in Compound1, $\quad(693.8 \pm 65.68 \quad(\mathrm{U} / \mathrm{mL})$ and3.69 $\pm 0.21(\mathrm{mM} / \mathrm{L})$, by $(602.2 \%$ and $1763.6 \%$ )

compound2,(195.6 \pm 9.95$)(\mathrm{U} / \mathrm{mL})$ and $(0.17 \pm 0$. $042(\mathrm{mM} / \mathrm{L})$ by $(97.99 \%, 14.14 \%)$ in compound $3,(383.9 \pm 20.62(\mathrm{U} / \mathrm{mL})$ and $(0.75 \pm 0.07(\mathrm{mM} / \mathrm{L})$ by $(288.6 \%$ and 278.6$)$ in compound $\quad 4 \quad(485.15 \quad \pm$ $49.25(\mathrm{U} / \mathrm{mL})$ and $(1.47 \pm 0.40) \quad(\mathrm{mM} / \mathrm{L})$ by (391.1\% and 642.4\%) in compound 5. $(\mathrm{p}<0.001)$.

(c) Positive Drug Groups of synthesized compounds (1, 2, 3, 4, and 5) $(196.6 \pm 6.34$ $(\mathrm{U} / \mathrm{mL})$ and $(0.42 \pm 0.023(\mathrm{mM} / \mathrm{L})$ by $(99.02 \%$ and $112.12 \%)$ in compound $1,(207.2 \pm 15.11$ $(\mathrm{U} / \mathrm{mL})$ and $(0.54 \pm 0.074(\mathrm{mM} / \mathrm{L})$ by $(109.7 \%$ and $172.7 \%)$ in compound $2,(163.12 \pm 14.42$ $(\mathrm{U} / \mathrm{mL})$ and $(0.47 \pm 0.018(\mathrm{mM} / \mathrm{L})$ by $(65.11 \%$ and $137.3 \%)$ in compound 3,(198.07 \pm 12.74 $(\mathrm{U} / \mathrm{mL})$ and $(0.43 \pm$ $0.024(\mathrm{mM} / \mathrm{L})$ by $100.4 \%$ and $117.1 \%)$

in compound $4,(210.77 \pm 16.67(\mathrm{U} / \mathrm{mL})$ and $(0.52 \pm 0.025(\mathrm{mM} / \mathrm{L})$ by $(113.3 \%$ and $162.6 \%)$ in compound $5(\mathrm{p}<0.001)$.

Also, MDA, NO and Arginase Activities were found to be decreased compared to positive control group(a)Preventive groupof synthesized compounds $(1,2,3,4$, and 5) $(16.44 \pm 1.71$

$(\mathrm{nmol} / \mathrm{ml}),(17.7 \pm 1.11(\mu \mathrm{mol} / 1)$ by $(61.5 \%$ and $65.4 \%$, ) and $(109.2 \pm 2.2(\mathrm{U} / \mathrm{L})$ by $(57.09 \%)$ in compound $1,(10.9 \pm 1.04(\mathrm{nmol} / \mathrm{ml}), 14.9$ $\pm 1.32(\mu \mathrm{mol} / 1)$ by $(74.49 \%$, and $71 \%)$, and , $(69.3 \pm 8.8(\mathrm{U} / \mathrm{L})$ by $(72.7 \%)$, in compound 2 ,$(32.35 \pm 1.94(\mathrm{nmol} / \mathrm{ml}), \quad(32.01 \pm 37.69$ $(\mu \mathrm{mol} / 1)$ by $(24.46 \%$ and $37.69 \%)$ and ,$(69.3 \pm 8.8$ (U/L) by $(72.7 \%)$ (in compound 3),(20.33 \pm 0.658 (nmol / ml),(20.69 \pm 0.807 $(\mu \mathrm{mol} / \mathrm{l})$ by $\quad(52.4 \% \quad$ and $59.7 \%$, and(170.7 $\pm 26.7(\mathrm{U} / \mathrm{L}) \quad$ by $\quad(33.7 \%)$ in compound $4,(11.45 \pm 0.948(\mathrm{nmol} / \mathrm{ml}), 19.22$ $\pm 0.758(\mu \mathrm{mol} / 1)$ by $(73.32 \%$ and $62.63 \%)$ and (141.9 $\pm 1.5(\mathrm{U} / \mathrm{L})$ by $(44.24 \%)$ in compound 5 ,respectively $(\mathrm{p}<0.001)$.

(b)Therapeutic groups of synthesized compounds (1, 2, 3, 4, and 5) $(20.2 \pm 7.8$ $(\mathrm{nmol} / \mathrm{ml}),(23.5 \pm 6.37(\mu \mathrm{mol} / 1)$ by $(45.25 \%$ and $58.9 \%$, and $(132.11 \pm 16.5$ (U/L) by $(48.09 \%)$ in compound1, (16.5 \pm 0.85 (nmol/ml) by $(61.93 \%),(20.9 \pm 0.74(\mu \mathrm{mol} / 1)$ by $(59.3 \%)$ and $(91.78 \pm 16.5$ (U/L)by $(63.93 \%)$ in compound 2,(39.25 \pm 2.24 $(\mathrm{nmol} / \mathrm{ml})$ by $8.15 \%,(40.96 \pm 3.54(\mu \mathrm{mol} / 1)$ by $(20.2 \%)$ and $(229.7 \pm 9.6$ (U/L) by $(9.74 \%)$, in compound $3,(26.28 \pm 2.51 \quad(\mathrm{nmol} / \mathrm{ml})$ by (36.69\%), , $\quad,(25.29 \pm 2.38(\mu \mathrm{mol} / \mathrm{l})$ by $(50.77 \%)$ and $\quad(205.26 \pm 10.5(\mathrm{U} / \mathrm{L})$ by $(92.04 \%)$,in compound 4 (15.88 \pm 1.349(nmol/ml)by $(63.03 \%),(21.38 \quad \pm$ $1.22(\mu \mathrm{mol} / \mathrm{l})$ by58.38\%)and(150.9 $\pm 9.6(\mathrm{U} / \mathrm{L})$ by $(40.7 \%)$ in compound $5,(p<0.001)$.

(c)Positive Drug Group of synthesized compounds $(\mathbf{1}, \mathbf{2}, \mathbf{3}, \mathbf{4}$, and $\mathbf{5})(19.9 \pm 8.09$ $(\mathrm{nmol} / \mathrm{ml})$ by $(51.8 \%),(23.7 \pm 6.5(\mu \mathrm{mol} / \mathrm{l})$ by $(55.4 \%)$ and $(102.34 \pm 6.47(\mathrm{U} / \mathrm{L})$ by $(59.78 \%)$ in compound1, $(20.7 \pm 1.04 \mathrm{nmol} / \mathrm{ml})$ by $(51.56 \%),(20.4 \pm 1.32(\mu \mathrm{mol} / 1)$ by $(60.29 \%)$ and $(93.26 \pm 15.74(\mathrm{U} / \mathrm{L})$ by $(65.67 \%)$ in compound 2 , (15.36 $\pm 1.17(\mathrm{nmol} / \mathrm{ml})$ by $(64.06 \%)$ $\pm 1.84(\mu \mathrm{mol} / \mathrm{l})$ by $(48.2 \%)$ and $(104.2 \pm 8.5(\mathrm{U} / \mathrm{L})$ by $(59.05 \%)$ in compound $3,(14.6$ $\pm 1.14(\mathrm{nmol} / \mathrm{ml} \quad$ by $(65.83 \%) \quad(23.4 \quad \pm 1.26$ $(\mu \mathrm{mol} / \mathrm{l}) \quad$ by $(54.45 \%) \quad$ and $(100.5 \quad \pm$

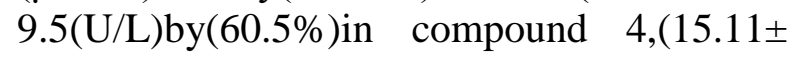
1.07 (nmol/ml)by(64.6\%),(19.63 $\pm 1.538(\mu \mathrm{mol} / \mathrm{l})$ by $(61.79 \%)$ and $(86.17 \pm 12.8(\mathrm{U} / \mathrm{L})$ by $(66.14 \%)$ in compound5,respectively $(\mathrm{p}<0.001)$, Table $(3,4$, 5,6, and7)for five Synthesized compounds according to(SOD, MDA ,NO ,TAC and Arginase).

\section{Discussion}

Cancer is a series of diseases that cause un controlled growth of the body cells ${ }^{(42)}$. Pyrazolines have various pharmacological Activities, such analgesic $^{(\mathbf{4 3})}$,antiinflammatory 
${ }^{(44)}$,antimicrobial ${ }^{(45)}$,antiamoebic ${ }^{(\mathbf{4 6})}$, antituberc ular ${ }^{(47)}$,hypoglycemic ${ }^{(48)}$,anticoagulant ${ }^{(49)}$, anti-

depressant $^{(\mathbf{5 0})}$, pesticide ${ }^{(\mathbf{5 1})}$, fungicide ${ }^{(\mathbf{5 2})}$, antibacterial $^{\mathbf{( 5 3 )}}$,and anticonvulsant activities ${ }^{(54)}$. pyrazolines are used as constituent part of a molecule in organic synthesis ${ }^{(\mathbf{5 5})}$, as optical bright ening agents for textiles, paper, and fabrics, and as a hole-conveying medium in photo conductive materials ${ }^{(56)}$.All the pyrazolines found to be free from toxicity as well as toxic symptoms even at high dose of $1000 \mathrm{mg} / \mathrm{kg}$ body weight and hence they were considered safe, The acute toxicity test conducted on Swiss mice shown that all the synthesized compounds were free of toxic symptoms even at concentration of $1000 \mathrm{mg} / \mathrm{kg}$ body weight andwere considered safe compounds Cornel et al., (2015) ${ }^{(57)}$.

On a hand, our tested compounds (Pyrazoline derivatives) reduced the volume and count of cancer cells, and increased the life span of mice. On the other hand, these compounds have anti-oxidant activity by affecting on antioxidant enzymes, Compound 2 [1Phenyl-3-methyl-4-(m-chlorophenyl

(azo)hydrazono)-2-pyrazoline-5-one] showed the greatest anti-tumor and anti-oxidant activities than other tested compounds. Compounds with electron withdrawing groups (halogens) on the aromatic ring favor antitumor, analgesic, and anti-inflammatory activities ${ }^{(\mathbf{5 8})}$. Also, 1, 2- pyrazoline nitrogen mustards with a phenyl and hydroxyl phenyl group at second and fifth position was found to be effective in the inhibition of cancer growth ${ }^{(59)}$.Pyrazoline compounds have a significant effect on enzymes that are native to normal tissue or those that could be associated with changes in metabolism and that are unique to cancer tissue. One of these enzymes is arginase. Arginase activity caused by the proliferation of tumor cells. Arginase and NO have very different effect on the growth of nearby tumor cells depending on which pathway is controlling . there is a significant increase in arginase activity and serum levels of NO in patients with breast cancer and these parameters used as a useful biological marker in breast cancer and as an indicator of breast cancer progression ${ }^{(\mathbf{6 0})}$. These compounds have antioxidant activity, this is due to the substitution in the aromatic ring system with halogens like chlorine can increase the antioxidant potency, as chlorine atom has lone pair electron as well as its electronegative power enhanced the formation and subsequent stabilization of the nitrogen-ring radical through intervening aromatic system property, it might have enhanced the power to absorb free radicals, especially reactive oxygen and reactive nitrogen species (ROS and RNS) ${ }^{(61)}$. Erhan Palaska et al., ${ }^{(62)}$ reported that 4-chloro and 4-methoxy substituents on the phenyl ring at position 3 of the pyrazoline ring (Meta position) increased the antitumor activity; the replacement of these groups by Nitro and methyl substituents decreased activity in mice. In general, (substitution by a halogen atom particularly, a chlorine atom) in the 'meta' position of the phenyl ring led to a better anti-tumor effect than that observed in the absence of any substituent ${ }^{(63)}$. These findings were in a line with many authors, Alka et al., ${ }^{(64)}$ who, reported that Pyrazoline ring containing compounds with alkylating groups can act as antitumor agents, further alkoxy groups and halogen atoms as substituent groups on the aromatic ring of the molecules shown significant anti-cancerous activity.

Nagwa and Nadia $(2015){ }^{(65)}$ : Who reported that synthesizedpyrazoline had antimicrobial activity. These compounds as molecular structure that is responsible for aparticular biological or pharma- cological interaction that it undergoes, with lipophilic properties such as chloro and bromo substituents offered the greatest antitumor activities.Also,Compounds with a methyl substituent at the para position of the phenyl ring showed good activity; while compounds with a nitro substituent at the para and meta positions, respectively, exhibited moderate activity. Rajendra,etal., (2005) ${ }^{(66)}$ reported the compounds possessing electron-releasing groups such as methoxy, on both the aromatic rings at positions 3 and 5 of pyrazolines, considerably enhanced the antitumor activity 
when compared to the pyrazolines having no substituents on the phenyl rings .

\section{Conclusion:}

Pyrazoline derivatives have anticancer and anti-oxidant activities. Compound (2) 1Phenyl-3 methyl-4-(mchlorophenyl(azo)hydrazono)-2-pyrazoline 5-one has a significant effect more than other synthesized compounds, as its halogen substitution in the meta position, which act as electron withdrawing groups on the aromatic ring chlorine atom has lone pair electron as well as its electronegative power enhanced the formation and posterior stabilization of the nitrogen-ring radical through interfere aromatic system property, it increased the power to absorb free radicals, especially reactive oxygen and reactive nitrogen species ,this favor antitumor, antioxidant ,analgesic, and anti-inflammatory activities.

\section{Acknowledgement:}

Many great thanks for the soul of Dr. Mohamed Abas Professor of Organic Chemistry, Mansoura University, Egypt, who offered me pyrazoline Compounds.

\section{Refrences:}

1. Mathur, G.; Nain, S.; Sharma, P.K. (2015), Cancer: An Overview. Acad. J. Cancer Res., 8, doi: 10.5829/ idosi. Ajcr . 2015 .8.1.9336.

2. Marella, A.; Ali, R.; Alam, T.; Saha, R.; Tanwar, O.; Akhter, M. Shaquiq uzzaman, M.; Alam, M.M. (2013) Pyrazolines: A biological review. Mini-Rev. Med. Chem., 13, 921-931.

3. Yusuf M., and Jain P., (2014): Synthetic and biological studies of pyrazolines and related heterocyclic compounds. Arabian Journal of Chemistry; 7 (5): 553-596.

4. Kumar, S.; Bawa, S.; Drabu, S.; Kumar, R.; Gupta, H (2009). Biological Activities of Pyrazoline Derivatives-A Recent Development. Recent Pat. Anti-Infect. Drug Discov., 4, 154-163.

5. Ramalingam S., Kannan Th., Perumal M., and Ganesamoorthy Th., (2012): Ecofriendly synthesis and anti-microbial activities of some 1-phenyl-3(5-bromothiophen-2-yl)-5-
(substitutedphenyl)-2-pyrazolines.Org Med Chem Lett.; 2: 20.

6. Havrylyuk D., Zimenkovsky B., Vasylenko O., Zaprutko L., Gzella A., and Lesyk R.,(2008): Synthesis of novel thiazolone-based compounds containing pyrazoline moiety and evaluation of their anticancer activity. Eur J Med Chem.; 42:1-9. 7. Eisinger J., Boens N., and Flores J., (1981): Fluorescence polarization study of human erythrocyte membranes with1-phenyl3-(2-naphthyl)-2pyrazoline as orientational probe. Biochim Biophysic Act.; 646:334-343.

8. Kokila P., Jayendra S.V., Yogesh D., and Viral M., (2012): Pyrazoline-Piperazine merged Compounds: Synthesis, spectral analysis and antibacterial evaluation. J. Chem. Bio. Phy. Sci. Sec.A Vol.2, No.2, 648653.

9. Li J.F., Guan B., Li D.X., and Dong C., (2007): Study on the fluorescence properties of a new intramolecular charge transfer compound 1, 5diphenyl-3-(N-ethylcarbazole3-yl)-2-pyrazoline. Spectrochim Act.; 68:404-408.

10. Ahmet O., Gulhan T., and Zafer A.K., (2008): Novel Analogues of 2 Pyrazoline: Synthesis, Characterization, and Antimyco bacterial Evaluation. Turk J Chem., 32, 529 538.

11. Wan-Sin L. , Ching K.Q., Tze S.C., Hoong-Kun F., Majal S., Badiadka N., and Balladka K.S., (2013): Synthesis and Crystal Structures of N-Substituted Pyrazolines . Molecules, 18, 2386-2396.

12. Akyol O., Zoroğlu SS., Armutcu F., Sahin S., Gurel A (2004). NitricOxide as a Factor in Neuropsychiatric Disorders. In vivo.; 18: 377-390.

13. Szabo C., Salzman AL., Ischiropoulos H. (1995) ,Peroxynitrite mediated oxidation of dihydrorho damine 123 occurs in early stages of endotoxic and haemorrhagic shock and ischemia-reperfusion injury. FEBS Lett .; 372: p. 229-232. 
14. Mayer B., Hemmens B (1997). Biosynthesis and action of nitric oxide in mammalian cells. Trends Biochem Sci.; 22: p.477-481.

15. A. Mora, M. A. Rangel, J. M. Fuentes, G.Soler and F. Centeno(2000)., Biochimica et Biophysica Acta (BBA) - Protein Structure and Molecular Enzymology,1476, 181

16. S. D. Cederbaum, H. Yu, W. W. Grody, R.M. Kern, P. Yoo, R. K. Lyer(2004)., Mol. Genet.Metab., 81, S38

17. M. F. Polat, S. Taysi, S. Polat, A. Boyuk and E. Bakan, (2003). Elevated serum arginase activity levels in patients with breast cancer. Surg. Today, 33, 655-61

18. Z.Porembska,G.Luboinski,A.

Chrzanowska, M. Mielczarek, J.Magnuska and A. Baranczyk-Kuzma, (2003). Arginase in patients with breast cancer. Clin Chim Acta:;328:105-11.

19. B.Straus, I. Cepelak and G. Festa, ibid., (1992). Arginase Activity In Breast Cancer Mol. Genet.Metab.210, 5

20. Erbas H, Aydogdu N, Usta U, Erten O. (2007) Protective role of carnitine in breast cancer via decreasing arginase activity and increasing nitric oxide. Cell Biol; 31: 1414-9.

21. Hecker M., Nematollahi H., Hey C., Busse R., Racke K. (1995) Inhibition of arginase by NG-hydroxy-L-arginine in alveolar macrophages :implications for the utilization of $\mathrm{L}$-arginine for nitric oxide synthesis.FEBS Lett.; 359: 251-154.

22. Meyer J., Richter N., Hecker M(1997). High-Performance Liquid Chromatographic Determination of Nitric Oxide SynthaseRelated Arginine Derivativesin Vitroandin Vivo. Anal. Biochem.; 247: 11-16.

23. Currie GA., Gyure L., Cifuentes L. (1979) Microenvironmental arginine depletion by macrophages in vivo. $\mathrm{Br} \mathrm{J}$ Cancer.; 39: 613-620.

24. Shearer JD., Richards JR., Mills CD., Caldwell MD(1997). Differential regulation of macrophage arginine metabolism: a proposed role in wound healing. Am J Physiol.; 272: 181-190.

25. Habib, O.M.O., Khalil, A.M., Kandeel, E.M. and Abdalla, E.B( 1986): synthesis of pyrazoline .Rev. Roum. Chim., (31): page 629

26. Laurence M.H., and Christopher J.M., (1989): Experimental organic chemistry: Principles and Practice (Illustrated). WileyBlackwell. p. 292.

27. Meier J., and Theakston R.D.G., (1986): Approximate LD50 determination of snake venuoms using eight to ten experimental animals. Toxicon, 24 (4), 395401.

28. McLiman W.F., Dairs E.V., Glover F.L., and Rake G.W., (1957): The submerged culture of mammalian cells. The Spinner Culture. J. Immunol., 79, 428.

29. Mazumdar U.K., Gupta M., Maiti S., and Mukherjee D., (1997): Antitumor activity of Hygrophila spinosa on Ehrlich ascites carcinoma and sarcoma-180 induced mice. Indian J Exp Biol 35: 473-477.

30. Satoh K., (1978) .Serum Lipid Peroxide in cerebrovascular disorders determined by a new colorimetric method. Clinica Chimica Acta, 90:page 37-43.

31. Montgomery H.A.C., and Dymock J.F., (1961): The determination of nitrite in water. Analyst, 86, page 414- 416.

32. Nishikimi M., Appaji N., and Yogi K., (1972): The occurrence of superoxide anion in the reaction of reduced phenazine methosulfate and molecular oxygen. Biochem. Bioph. Res. Commun 46: 849 - 854.

33. Koracevic D., Koracevic G., Djordjevic, V.,Andrejevic S., and Cosic, V., (2001): Method for the measurement of antioxidant activity in human fluids. J. Clin. Pathol. ; 54:356-361.

34. Marsch et al.,(1965), The colorimetric determination of urea condensation with 
diacetyl monoxime in an acid medium in the presence of ferric chlorid(oxidant) and carbazide (accelerator), Clin. Chim. Acta 11, page 519-522.

35. Levesque R., (2007): $\quad$ SPSS Programming and Data Management: A Guide for SPSS and SAS Users, Fourth Edition, SPSS Inc., Chicago.

36. Kalpana Divekar1, Shivakumar Swamy2, V. Murugan1(2014), Synthesis, Characterization and Anticancer activity of some novel pyrazoline derivatives, eIJPPR, p.1-13

37. Freitas E.S., Leite E.D., Silva A.E., Ocarino N.M.; Ferreira E., Gomes M.G., Cassali G.D., and Serakides R., (2006): Effect of Thyroxine and Propylthiouracil in Ehrlich Ascitic Tumor Cells. Int. J. Morphol., 24(4):p665-671.

38. Amr Y.E., (1986): Studies on the effect of Dietary Magnesium and manganese on Experimental Tumor Cell (in mice). Thesis, Ain-Shams University, p.35.

39. Diab A.A., El-Sayed A. A., Hendawy A.A., Zahra M.H.andHamzaR.Z(2012). Antioxidant Role of both Propolis and Ginseng against Neurotoxicity of Chlorpyrifos and Profenofos in Male Rats. Life Science Journal;9(3)

40. Hayat M.S. (2001): Effect of inositol hexaphosphate (IP6) on the activity of antioxidant defense system in mice loaded with solid tumor Egyptian Journal of biochemistry and molecular biology .24,p.137-153.

41. Lindsay C. Burrage1,2, Qin Sun1, Sarah H. Elsea1, Ming-Ming Jiang1, Sandesh C.S. Nagamani1,2, Arthur E. Frankel3, Everett Stone4, Susan E. Alters5, Dale E. Johnson5, Scott W. Rowlinson5, George Georgiou4, (2015) Human recombinant arginase enzyme reduces plasma arginine in mouse models of
arginasedeficiency,Hum.Mol.Genet..H.Lee1,2 ,p. 10-22

42. American Cancer Society, (2016): Breast Cancer Facts \& Figures 2015-2016. Atlanta: American Cancer Society, Inc. 2015. 43. Sahu S.K., Banerjee M., Samantray A., Behera C., and Azam M.A. (2008): Synthesis, analgesic, anti-inflammatory and antimicrobial activities of some novel pyrazoline derivatives. Trop J Pharm Res 7(2):961-968.

44. Karabasanagouda T, Adhikari AV, and Girisha M (2009): Synthesis of some new pyrazolines and isoxazoles carrying 4ethylthiophenyl moiety as potential analgesic and anti-inflammatory agents. Indian J Chem 48B(3):430-437.

45. Chawla R, Sahoo U, Arora A, Sharma PC, and Radhakrishnan V (2010): Microwave assisted synthesis of some novel 1-pyrazoline derivatives as possible antimicrobial agents. Acta Polo Pharm-Drug Res 67(1):55-61.

46. Mbarki S, Dguigui $K$, and Hallaoui ME (2011): Construction of 3D-QSAR models to predict antiamoebic activities of pyrazoline and dioxazoles derivatives.J Mater Environ Sci 2(1):61-70.

47. Rahman M.A., and Siddiqui A.A., (2010): Pyrazoline derivatives: a worthy insight into the recent advances and potential pharmacological activities. Int J Pharm Sci Drug Res 2(3):165-175

48. Sridevi C., Balaji K., Naidu A., Kavimani S., Venkappayya D., Suthakaran R., and Parimala S., (2009): Synthesis of some phenylpyrazolo benzothiazolo quinoxaline derivatives. Int J Pharm Tech Res 1(3):816-821

49. Levai A., and Jeko J. (2009): Synthesis of 5-aryl-1-carboxyphenyl-3-(3-coumarinyl)2-pyrazolines. ARKIVOC VI: 63-70.

50. Zhao P.L., Wang F., Zhang M.Z., Liu Z.M., Huang W., and Yang G.F., (2008): Synthesis, fungicidal and insecticidal activities of $\beta$-methoxyacrylate containing $\mathrm{N}$ - 
acetyl pyrazoline derivatives. J Agric Food Chem 56(22):10767-10773.

51. Kini S., and Gandhi A.M., (2008):

Novel 2-pyrazoline derivatives as potential antibacterial and antifungal agents. Indian $\mathbf{J}$ Pharm Sci 70(1):105-108.

52. Siddiqui A.A., Rahman M.A., Shaharyar M., and Mishra R., (2010): Synthesis and anticonvulsant activity of some substituted 3,5-diphenyl-2-pyrazoline-1carboxamide derivatives. Chem Sci J 1:1-10.

53. Gowramma B., Jubie S., Kalirajan R., Gomathy S., and Elango K., (2009): Synthesis, anticancer activity of some 1-(Bis $\mathrm{N}, \quad \mathrm{N}$-(Chloroethyl)-amino acetyl)-3,5disubstituted 1,2-pyrazolines. Int $\mathbf{J}$ Pharm Tech Res 1(2):347-352.

54. Padmavathi V., Sumathi R.P., Chandrasekar Babu N., and Bhaskar D. (1999): 1,3-Dipolar cycloaddition of dipolar reagents to bifunctional olefins in the presence of chloramine-T (CAT). J Chem Res (S):610-611.

55. Klimova E.I., Maartnez Garca M., Klimova Berestneva T., Alvarez Toledano C., Alferdo Toskano R., and Ruz Ramres L., (1999): The structure of bicyclic ferro cenyl methylene substituted 2-pyrazolines and their reactions with azodicarboxylic acid Nphenylimide. J Org Metal Chem 585(1):106114.

56. Thirunarayanan G., (2011): Solvent free synthesis, spectral studies and antioxidant activities of some 6 -substituted $\omega$ bromo-2-naphthyl ketones and their esters. Indian J Chem 50B(4):593-604

57. Cornel Chiriţa, Aurelia Nicoleta Cristea, Manuella Militaru, Simona Negreş, Cristina Elena Zbarcea, Diana Camelia Nuţa(2015): Pharmacological Evaluation Of Acute And Subacute Toxicity And Antidepressant Effect After Acute Administration Of Novel N-substituted Benzamides, Farmacia; 58:1:21-28.

58. Jainey P.J., and Bhat I.K., (2012): Antitumor, Analgesic, and Antiinflammatory Activities of Synthesized Pyrazolines, J Young Pharm.; 4(2): 82-87
59. Gowramma B., Jubie S., Kalirajan R., and Gomathy S., (2009): Synthesis, anticancer activity of some 1-(Bis N, N(Chloroethyl)-amino acetyl)-3, 5disubstituted 1, 2-pyrazolines - Int J Pharm Tech Res, 1(2):347-352.

60. Amal A. Mahmoud1, Sahar E.M. ElSaid1, Manal A.M. Mandour1, Madeha M. Zakhary1 and Doaa Wadie Maximous2 (2009), Arginase Activity In Breast Cancer: Is It A Significant Biomarker ? Bull. Pharm. Sci., Assiut University, Vol. 32, Part 2, pp. 241-247.

61. Vidyashree H.S.J., BalakrishnA K., and Kotathattu S.G., (2014): Synthesis and antioxidant activity study of pyrazoline carrying an arylfuran/arylthiophene moiety. J. Serb. Chem. Soc. 79 (12) 1469-1475.

62. Palaska E., Aytemir M., Uzbay I.T., and Erol D., (2001): Synthesis of antidepressant activities of some 3, 5diphenyl-2-pyrazolines. European Journal of Medicinal Chemistry, 36 (6):539-43.

63. Kempen I., Papapostolou D., Thierry N., Pochet L., Counerotte S., Masereel B., Foidart J-M, Reboud-Ravaux M., Noe A., and Pirotte B., (2003): 3-Bromophenyl 6acetoxymethyl-2-oxo-2H-1-benzopyran-

3 carboxylate inhibits cancer cell invasion in vitro and tumor growth in vivo. British Journal of Cancer. 88, 1111 - 1118.

64. Alka P., Harshita G., and Nazish K., (2015): Microwave Assisted Synthesis Of Some Pyrazoline Derivatives As Potent Anticancer Agent: A Review. Asian Journal of Science and Technology Vol. 6, Issue 08, pp. 1673-1676.

65. Nagwa M.M.H., and Nadia Y.M.A., (2015): Synthesis ,Characterization ,Antimicrobial ,Screening and Free-Radical Scavenging Activity of Some Novel Substituted Pyrazoles, Molecules 2015, 20, 10468-1048.

66. Rajendra Y., Lakshmana Rao A., Prasoona L., Murali K., Ravi Kumar $\mathbf{P}$ (2005). Pyrazoline derivatives ,Bio org Med Chem. Lett. 15(22):p5030-5034. 
Structures and IR Spectra Of Five Synthesized Pyrazoline Derivatives .

1) Compound 1: Phenyl-3methyl-4-(o-chlorophenyl(azo)hydrazono)-2-pyrazoline-5-one .
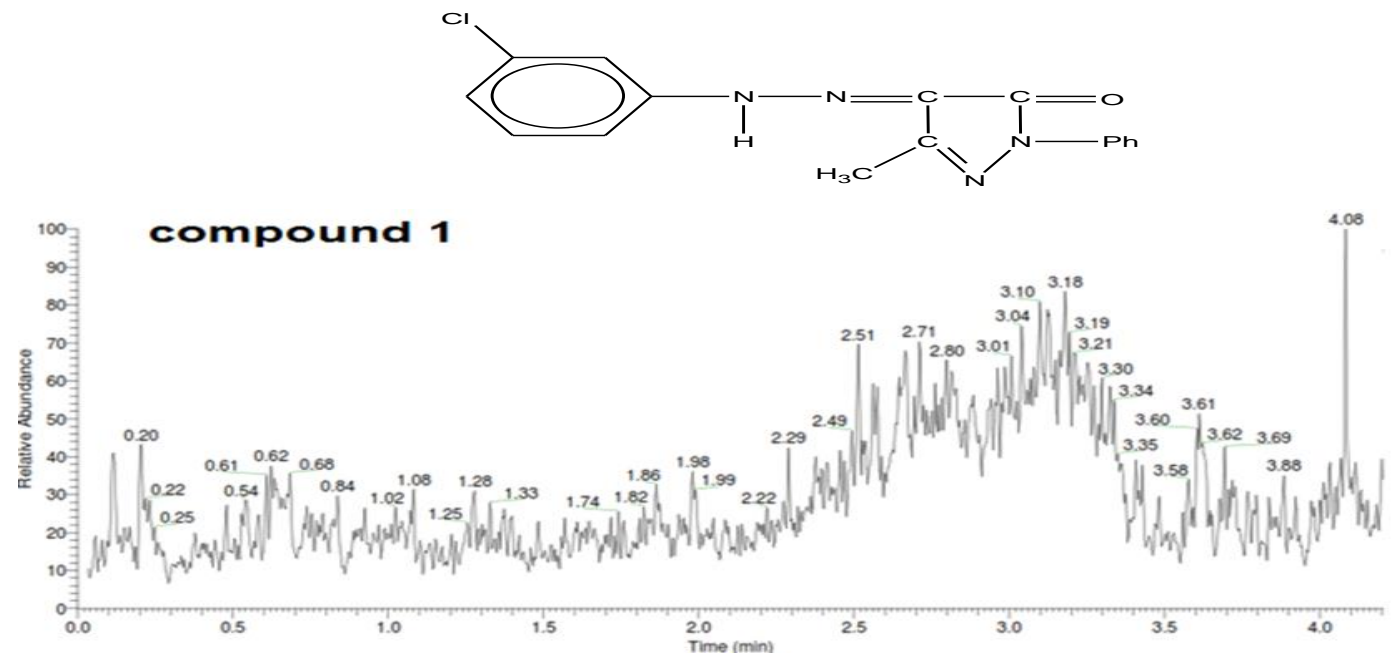

Figure (1)

2) Compound 2: Phenyl-3methyl-4-(m-chlorophenyl(azo)hydrazono)-2-pyrazoline-5-one .
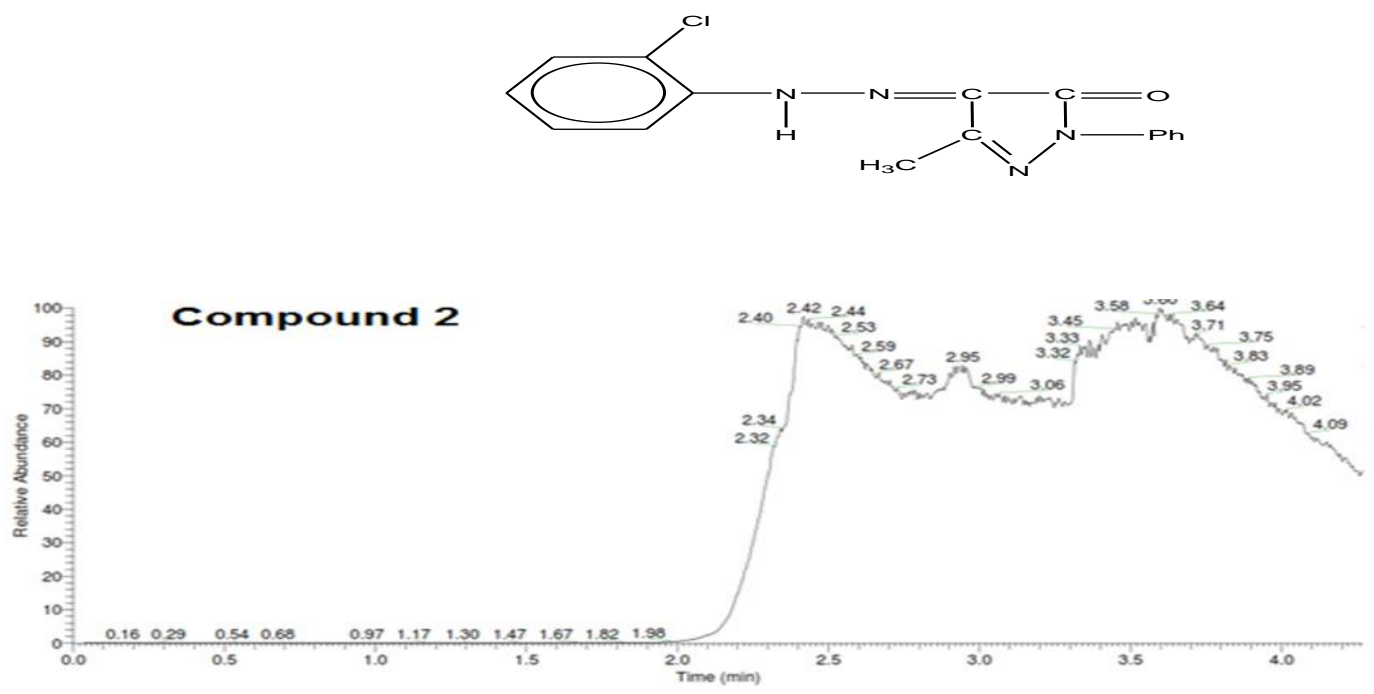

Figure (2)

(3) Compound 3:Phenyl-3methyl-4-(m-nitrophenyl(azo)hydrazono)-2-pyrazoline-5-one .
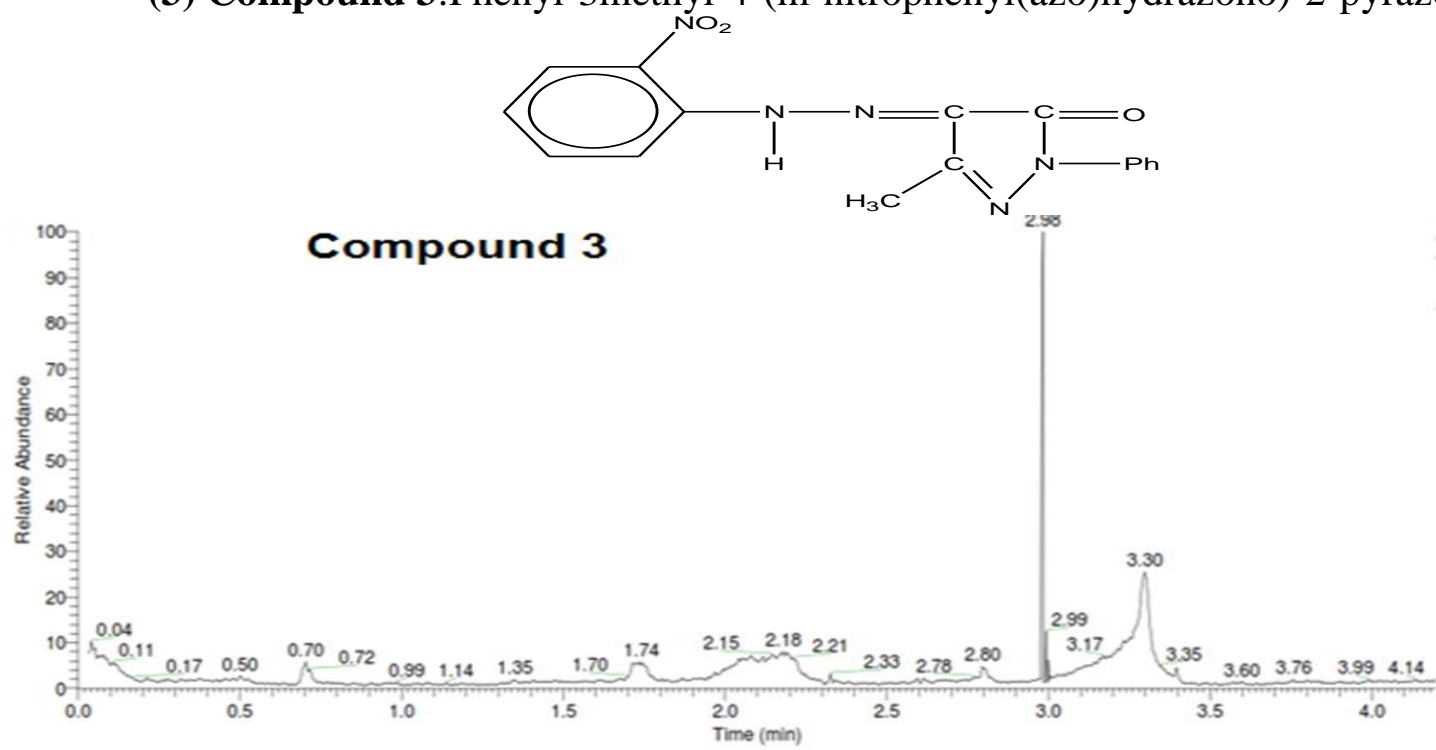

Figure (3) 
(4) Compound 4:Phenyl-3methyl-4-(o-methylphenyl(azo)hydrazono)-2-pyrazoline-5-one .
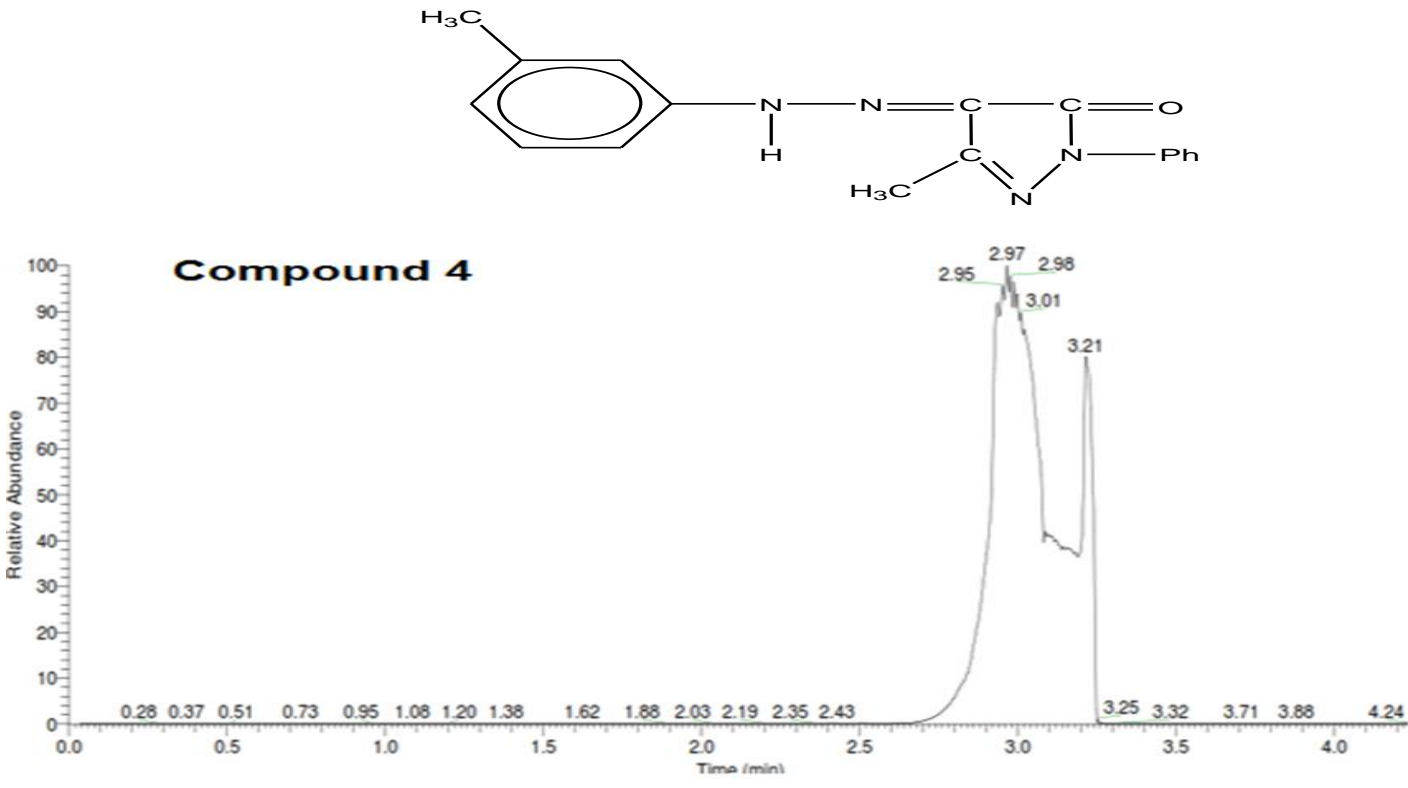

Figure (4)

(5) Compound 5:Phenyl-3methyl-4-(m-methoxyphenyl(azo)hydrazono)-2-pyrazoline-5-one.<smiles></smiles>

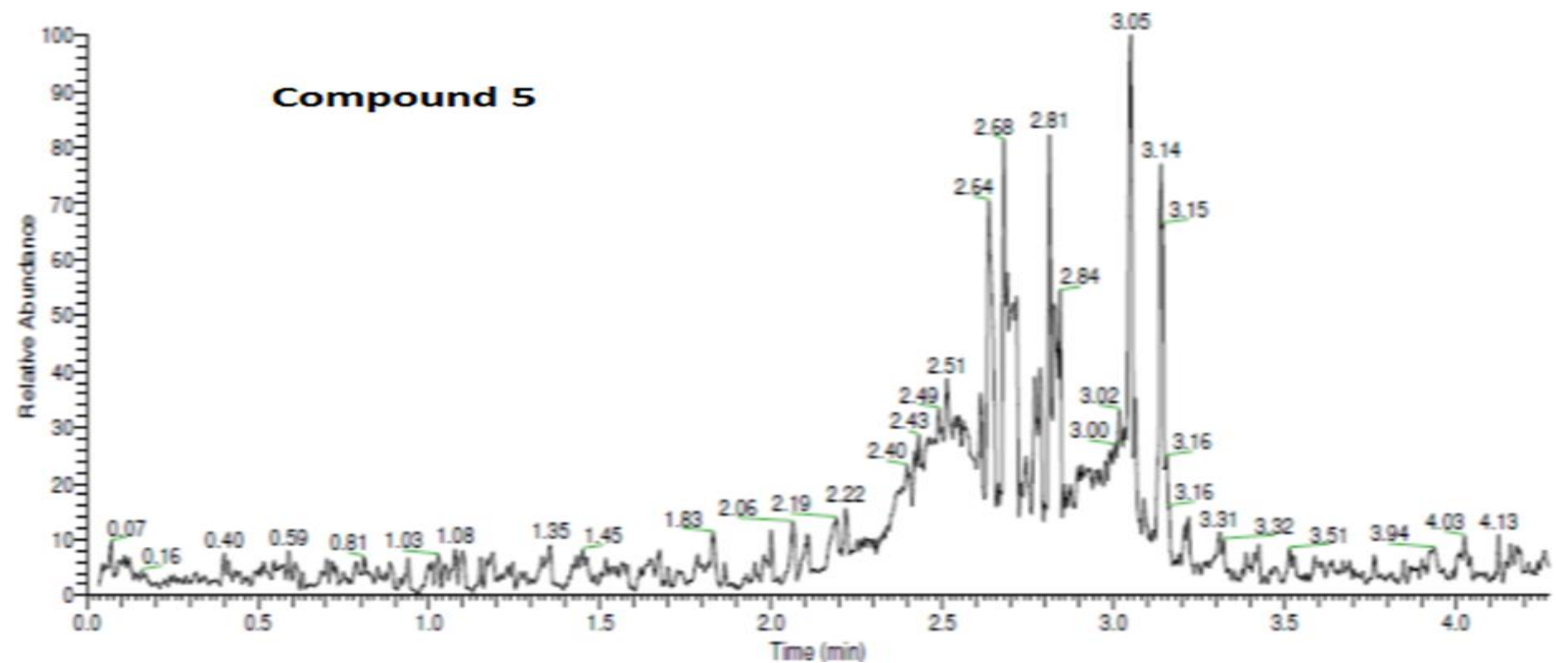

Figure(5) 
Table (1): Effect of compounds $(1,2,3,4$, and 5$)$ on volume and viability of EAC cell $\left(\times 10^{6}\right.$ cell/ $\left.\mathrm{ml}\right):$ in studied groups:

\begin{tabular}{|c|c|c|c|c|c|c|c|c|c|c|c|c|}
\hline & & & \multicolumn{4}{|c|}{ Compound 1} & \multicolumn{4}{|c|}{ Compound 2} & & Compou \\
\hline Group & \multicolumn{2}{|c|}{$\begin{array}{c}\text { Positive Control } \\
\text { Group }\end{array}$} & \multicolumn{2}{|c|}{ Preventive Group } & \multicolumn{2}{|c|}{$\begin{array}{c}\text { Therapeutic } \\
\text { Group }\end{array}$} & \multicolumn{2}{|c|}{ Preventive Group } & \multicolumn{2}{|c|}{$\begin{array}{c}\text { Therapeutic } \\
\text { Group }\end{array}$} & \multicolumn{2}{|c|}{ Preventive Group } \\
\hline rameter & $\begin{array}{c}\text { Tumor } \\
\text { Volume } \\
\text { (ml) }\end{array}$ & $\begin{array}{c}\text { EAC cells } \\
\text { Count } \\
(\times 106)\end{array}$ & $\begin{array}{c}\text { Tumor } \\
\text { Volume } \\
\text { (ml) }\end{array}$ & $\begin{array}{c}\text { EAC } \\
\text { cells } \\
\text { Count } \\
(\times 106)\end{array}$ & $\begin{array}{c}\text { Tumor } \\
\text { Volume } \\
\text { (ml) }\end{array}$ & $\begin{array}{c}\text { EAC } \\
\text { cells } \\
\text { Count } \\
(\times 106)\end{array}$ & $\begin{array}{c}\text { Tumor } \\
\text { Volume } \\
\text { (ml) }\end{array}$ & $\begin{array}{c}\text { EAC } \\
\text { cells } \\
\text { Count } \\
(\times 106)\end{array}$ & $\begin{array}{c}\text { Tumor } \\
\text { Volume } \\
\text { (ml) }\end{array}$ & $\begin{array}{c}\text { EAC } \\
\text { cells } \\
\text { Count } \\
(\times 106)\end{array}$ & $\begin{array}{c}\text { Tumor } \\
\text { Volume } \\
\text { (ml) }\end{array}$ & $\begin{array}{c}\text { EAC } \\
\text { cells } \\
\text { Count } \\
(\times 106)\end{array}$ \\
\hline $\begin{array}{l}\text { Mean } \pm \\
\text { SD. }\end{array}$ & $\begin{array}{l}5.8 \pm \\
0.24\end{array}$ & $\begin{array}{c}188.7 \pm \\
4.63\end{array}$ & $\begin{array}{l}1.4 \pm \\
0.12\end{array}$ & $\begin{array}{c}40.8 \\
\pm 1.18\end{array}$ & $\begin{array}{l}2.4 \pm \\
0.11\end{array}$ & $\begin{array}{l}61.28 \\
\pm 1.76\end{array}$ & $\begin{array}{l}\text { No } \\
\text { EAC }\end{array}$ & $\begin{array}{l}\text { No } \\
\text { EAC }\end{array}$ & $\begin{array}{l}0.7 \pm \\
0.09\end{array}$ & $\begin{array}{c}23.6 \pm \\
0.95\end{array}$ & $\begin{array}{c}4.3 \\
\pm 0.12\end{array}$ & $120.9 \pm 1.8$ \\
\hline Change & --------- & ------------ & $74.2 \%$ & $78.29 \%$ & $57.7 \%$ & $67.5 \%$ & ------- & ------ & $87.19 \%$ & $87.44 \%$ & $24.38 \%$ & $35.9 \%$ \\
\hline $\mathbf{P}$ & ---------- & --------------. & $0.001 * *$ & $0.001 * *$ & $0.001 * *$ & $0.001 * *$ & $0.001 * *$ & $0.001 * *$ & $0.001 * *$ & $0.001 * *$ & $0.001 * *$ & $0.001 * *$ \\
\hline
\end{tabular}

$* \mathrm{p}<0.05=$ significant; $\mathrm{p}<0.01 * *=$ highly significant as treated group compared to negative group

Table (2): Effect of Pyrazoline Derivatives Compounds (1, 2, 3, 4,and 5) on life span prolongation

\begin{tabular}{|c|c|c|c|c|c|c|}
\hline Group & $\begin{array}{c}\text { Positive } \\
\text { Control } \\
\text { Group }\end{array}$ & $\begin{array}{c}\text { Compound (1) } \\
\text { Treated Group }\end{array}$ & $\begin{array}{c}\text { Compound (2) } \\
\text { Treated Group }\end{array}$ & $\begin{array}{c}\text { Compound (3) } \\
\text { Treated Group }\end{array}$ & $\begin{array}{c}\text { Compound (4) } \\
\text { Treated Group }\end{array}$ & $\begin{array}{c}\text { Compound (5) } \\
\text { Treated Group }\end{array}$ \\
\hline Days & 16 & 23 & 29 & 21 & 25 & 26 \\
\hline $\begin{array}{c}\text { Change } \\
\%\end{array}$ & ------ & 44 & 81 & 31 & 56 & 63 \\
\hline $\begin{array}{c}\text { T/C ratio } \\
\%\end{array}$ & ------- & 144 & 181 & 131 & 156 & 163 \\
\hline
\end{tabular}

$\mathrm{T}=$ number of days the treated animals survived

$\mathrm{C}=$ number of days the control animals survived

Increase in life span $=(\mathrm{T}-\mathrm{C}) / \mathrm{C} \times 100$

$(\mathrm{T} / \mathrm{C}$ Ratio $=$ Mean survival time of treated $/$ Mean survival time of control $\times 100)$ 


\section{Effect of Synthesised Pyrazoline Compounds (1,2,3,4,and 5) On Enzymes:}

Table (3): Effect of (Compound 1) on MDA, NO, SOD, TAC and Arginase in plasma:

\begin{tabular}{|c|c|c|c|c|c|c|c|c|c|c|}
\hline \multirow[t]{2}{*}{ Variables } & \multicolumn{2}{|c|}{$\begin{array}{l}\text { Negative control group } \\
\text { (Gr.I) }\end{array}$} & \multicolumn{2}{|c|}{$\begin{array}{c}\text { Positive Control Group } \\
\text { (Gr. II) }\end{array}$} & \multicolumn{2}{|c|}{$\begin{array}{c}\text { Preventive Group } \\
\text { (Gr.III a) }\end{array}$} & \multicolumn{2}{|c|}{$\begin{array}{c}\text { Therapeutic Group } \\
\text { (Gr.III b) }\end{array}$} & \multicolumn{2}{|c|}{$\begin{array}{l}\text { +ve Drug } \\
\text { (Gr.III c) }\end{array}$} \\
\hline & $\begin{array}{l}\text { Mean } \pm \\
\text { SD. }\end{array}$ & $\begin{array}{c}\% \\
\text { Change }\end{array}$ & $\begin{array}{l}\text { Mean } \pm \\
\text { SD. }\end{array}$ & $\begin{array}{c}\% \\
\text { Change }\end{array}$ & $\begin{array}{l}\text { Mean } \pm \\
\text { SD. }\end{array}$ & $\begin{array}{c}\% \\
\text { Change }\end{array}$ & $\begin{array}{l}\text { Mean } \pm \\
\text { SD. }\end{array}$ & $\begin{array}{c}\% \\
\text { Change }\end{array}$ & $\begin{array}{l}\text { Mean } \pm \\
\text { SD. }\end{array}$ & $\begin{array}{c}\% \\
\text { Change }\end{array}$ \\
\hline $\begin{array}{c}\text { MDA } \\
\mathrm{nmol} / \mathrm{ml}\end{array}$ & $\begin{array}{c}11.6 \pm \\
0.73\end{array}$ & $72.6 \%$ & $\begin{array}{c}42.74 \pm \\
1.89\end{array}$ & ----- & $\begin{array}{c}16.44 \pm \\
1.71\end{array}$ & $61.5 \%$ & $\begin{array}{c}20.2 \pm \\
7.8\end{array}$ & $45.25 \%$ & $\begin{array}{c}19.9 \pm \\
8.09\end{array}$ & $51.8 \%$ \\
\hline $\begin{array}{c}\text { NO } \\
\mu \mathrm{mol} / \mathrm{l}\end{array}$ & $\begin{array}{c}21.4 \pm \\
2.13\end{array}$ & $58.34 \%$ & $\begin{array}{c}51.3 \pm \\
3.9\end{array}$ & ----- & $\begin{array}{c}17.77 \pm \\
1.11\end{array}$ & $65.4 \%$ & $\begin{array}{c}23.5 \pm \\
6.37\end{array}$ & $58.9 \%$ & $\begin{array}{c}23.7 \pm \\
6.5\end{array}$ & $55.4 \%$ \\
\hline $\begin{array}{l}\text { SOD } \\
\text { U/mL }\end{array}$ & $\begin{array}{c}203.8 \pm \\
3.87\end{array}$ & $-106.3 \%$ & $\begin{array}{l}98.78 \pm \\
4.05\end{array}$ & ----- & $\begin{array}{c}648.49 \pm \\
39.9\end{array}$ & $-556.4 \%$ & $\begin{array}{l}516.35 \pm \\
40.85\end{array}$ & $-422.7 \%$ & $\begin{array}{c}196.6 \pm \\
6.34\end{array}$ & $-99.02 \%$ \\
\hline $\begin{array}{c}\text { TAC } \\
\mathbf{m M} / \mathbf{L}\end{array}$ & $\begin{array}{c}0.391 \pm \\
0.059\end{array}$ & $-97.47 \%$ & $\begin{array}{c}0.198 \pm \\
0.041\end{array}$ & ----- & $\begin{array}{l}3.49 \pm \\
0.292\end{array}$ & $1662.6 \%$ & $\begin{array}{c}2.62 \pm \\
0.22\end{array}$ & $1223.2 \%$ & $\begin{array}{l}0.42 \pm \\
0.023\end{array}$ & $-112.12 \%$ \\
\hline $\begin{array}{c}\text { Arginase } \\
\text { U /L }\end{array}$ & $\begin{array}{c}91.28 \pm \\
8.02\end{array}$ & $64.13 \%$ & $\begin{array}{c}254.5 \pm \\
21.3\end{array}$ & ----- & $\begin{array}{c}109.2 \pm \\
2.2\end{array}$ & $57.09 \%$ & $\begin{array}{c}132.11 \pm \\
16.5\end{array}$ & $48.09 \%$ & $\begin{array}{c}102.34 \pm \\
6.7\end{array}$ & $59.78 \%$ \\
\hline
\end{tabular}

${ }^{*} \mathrm{p}<0.05=$ significant; $\mathrm{p}<0.01 * *=$ highly significant.compared to the negative control group

Table (4): Effect of (Compound 2) on "MDA, NO, SOD, TAC and Arginase in plasma:

\begin{tabular}{|c|c|c|c|c|c|c|c|c|c|c|}
\hline \multirow[t]{2}{*}{ Variables } & \multicolumn{2}{|c|}{$\begin{array}{l}\text { Negative control group } \\
\text { (Gr.I) }\end{array}$} & \multicolumn{2}{|c|}{$\begin{array}{l}\text { Positive Control } \\
\text { Group (Gr. II) }\end{array}$} & \multicolumn{2}{|c|}{$\begin{array}{l}\text { Preventive Group } \\
\text { (Gr.IV a) }\end{array}$} & \multicolumn{2}{|c|}{$\begin{array}{l}\text { Therapeutic Group } \\
\text { (Gr.IV b) }\end{array}$} & \multicolumn{2}{|c|}{$\begin{array}{l}\text { +ve Drug } \\
\text { (Gr.IVc) }\end{array}$} \\
\hline & $\begin{array}{l}\text { Mean } \pm \\
\text { SD. }\end{array}$ & $\%$ Change & $\begin{array}{l}\text { Mean } \pm \\
\text { SD. }\end{array}$ & $\begin{array}{l}\% \\
\text { Change }\end{array}$ & $\begin{array}{l}\text { Mean } \pm \\
\text { SD. }\end{array}$ & $\begin{array}{l}\% \\
\text { Change }\end{array}$ & $\begin{array}{l}\text { Mean } \pm \\
\text { SD. }\end{array}$ & $\begin{array}{l}\% \\
\text { Change }\end{array}$ & $\begin{array}{l}\text { Mean } \pm \\
\text { SD. }\end{array}$ & $\begin{array}{l}\% \\
\text { Change }\end{array}$ \\
\hline MDA nmol/ml & $\begin{array}{c}11.6 \pm \\
0.37\end{array}$ & $72.6 \%$ & $\begin{array}{c}42.74 \pm \\
1.89\end{array}$ & ----- & $\begin{array}{c}10.9 \pm \\
1.04\end{array}$ & $74.49 \%$ & $\begin{array}{c}16.5 \pm \\
0.85\end{array}$ & $61.39 \%$ & $\begin{array}{c}20.7 \pm \\
1.04\end{array}$ & $51.56 \%$ \\
\hline $\begin{array}{c}\text { NO } \\
\mu \mathrm{mol} / \mathrm{l}\end{array}$ & $\begin{array}{l}21.4 \pm \\
2.13\end{array}$ & $58.34 \%$ & $\begin{array}{l}51.38 \pm \\
3.9\end{array}$ & ----- & $\begin{array}{c}14.9 \pm \\
1.32\end{array}$ & $71 \%$ & $\begin{array}{c}20.9 \pm \\
0.74\end{array}$ & $59.3 \%$ & $\begin{array}{c}20.4 \pm \\
1.32\end{array}$ & $60.29 \%$ \\
\hline $\begin{array}{l}\text { SOD } \\
\text { U/mL }\end{array}$ & $\begin{array}{c}203.8 \pm \\
3.87\end{array}$ & $-106.3 \%$ & $\begin{array}{l}98.78 \pm \\
4.05\end{array}$ & ----- & $\begin{array}{l}916.4 \pm \\
38.54\end{array}$ & $-827 \%$ & $\begin{array}{l}693.8 \pm \\
65.68\end{array}$ & $-602.2 \%$ & $\begin{array}{c}207.2 \pm \\
15.11\end{array}$ & $-109.7 \%$ \\
\hline $\begin{array}{l}\text { TAC } \\
\mathrm{mM} / \mathrm{L}\end{array}$ & $\begin{array}{c}0.391 \pm \\
0.059\end{array}$ & $-97.47 \%$ & $\begin{array}{c}0.198 \pm \\
0.041\end{array}$ & ---- & $\begin{array}{l}4.7 \pm \\
0.429\end{array}$ & $2273.7 \%$ & $\begin{array}{c}3.69 \pm \\
0.21\end{array}$ & $-1763.6 \%$ & $\begin{array}{l}0.54 \pm \\
0.074\end{array}$ & $-172.7 \%$ \\
\hline $\begin{array}{c}\text { Arginase } \\
\mathbf{U} / \mathbf{L}\end{array}$ & $\begin{array}{l}91.28 \pm \\
8.02\end{array}$ & $64.13 \%$ & $\begin{array}{c}254.5 \pm \\
21.3\end{array}$ & ----- & $\begin{array}{c}69.3 \pm \\
8.8\end{array}$ & $72.7 \%$ & $\begin{array}{c}91.78 \pm \\
6.92\end{array}$ & $63.93 \%$ & $\begin{array}{c}93.26 \pm \\
15.74\end{array}$ & $65.67 \%$ \\
\hline
\end{tabular}

*p $<0.05=$ significant; $\mathrm{p}<0.01 * *=$ highly significant.

Table (5): Effect of (Compound 3) on MDA, NO, SOD, TAC and Arginase in plasma:

\begin{tabular}{|c|c|c|c|c|c|c|c|c|c|c|}
\hline \multirow[t]{2}{*}{ Variables } & \multicolumn{2}{|c|}{$\begin{array}{c}\text { Negative control group } \\
\text { (Gr.I) }\end{array}$} & \multicolumn{2}{|c|}{$\begin{array}{c}\text { Positive Control Group } \\
\text { (Gr. II) }\end{array}$} & \multicolumn{2}{|c|}{$\begin{array}{c}\text { Preventive Group } \\
\text { (Gr.III a) }\end{array}$} & \multicolumn{2}{|c|}{$\begin{array}{c}\text { Therapeutic Group } \\
\text { (Gr.III b) }\end{array}$} & \multicolumn{2}{|c|}{$\begin{array}{l}\text { +ve Drug } \\
\text { (Gr.III c) }\end{array}$} \\
\hline & $\begin{array}{l}\text { Mean } \pm \\
\text { SD. }\end{array}$ & $\%$ Change & $\begin{array}{l}\text { Mean } \pm \\
\text { SD. }\end{array}$ & $\begin{array}{c}\% \\
\text { Change }\end{array}$ & $\begin{array}{l}\text { Mean } \pm \\
\text { SD. }\end{array}$ & $\begin{array}{c}\% \\
\text { Change }\end{array}$ & $\begin{array}{l}\text { Mean } \pm \\
\text { SD. }\end{array}$ & $\begin{array}{c}\% \\
\text { Change }\end{array}$ & $\begin{array}{l}\text { Mean } \pm \\
\text { SD. }\end{array}$ & $\begin{array}{c}\% \\
\text { Change }\end{array}$ \\
\hline MDA nmol/ml & $\begin{array}{c}11.6 \pm \\
0.37\end{array}$ & $72.6 \%$ & $\begin{array}{c}42.74 \pm \\
1.89\end{array}$ & ---- & $\begin{array}{l}32.35 \pm 1 \\
94\end{array}$ & $24.46 \%$ & $\begin{array}{l}39.25 \pm \\
2.24\end{array}$ & $8.15 \%$ & $\begin{array}{c}15.36 \pm 1 \\
17\end{array}$ & $64.06 \%$ \\
\hline $\begin{array}{c}\text { NO } \\
\mu \mathrm{mol} / \mathrm{l}\end{array}$ & $\begin{array}{l}21.4 \pm \\
2.13\end{array}$ & $58.34 \%$ & $\begin{array}{l}51.38 \pm \\
3.9\end{array}$ & ----- & $\begin{array}{l}32.01 \pm 1 \\
65\end{array}$ & $37.69 \%$ & $\begin{array}{c}40.96 \pm \\
3.54\end{array}$ & $20.2 \%$ & $\begin{array}{c}26.6 \pm \\
1.84\end{array}$ & $48.2 \%$ \\
\hline $\begin{array}{l}\text { SOD } \\
\text { U/mL }\end{array}$ & $\begin{array}{c}203.8 \pm \\
3.87\end{array}$ & $-106.3 \%$ & $\begin{array}{l}98.78 \pm \\
4.05\end{array}$ & ----- & $\begin{array}{l}231.3 \pm 31 \\
.89\end{array}$ & $134.13 \%$ & $\begin{array}{l}195.6 \pm \\
9.95\end{array}$ & $-97.99 \%$ & $\begin{array}{l}163.12 \pm 1 \\
4.42\end{array}$ & $-65.11 \%$ \\
\hline $\begin{array}{c}\text { TAC } \\
\mathbf{m M} / \mathbf{L}\end{array}$ & $\begin{array}{c}0.391 \pm \\
0.059\end{array}$ & $-97.47 \%$ & $\begin{array}{c}0.198 \pm \\
0.041\end{array}$ & ----- & $\begin{array}{c}0.193 \pm \\
0.021\end{array}$ & $2.5 \%$ & $\begin{array}{c}0.17 \pm \\
0.0429\end{array}$ & $14.14 \%$ & $\begin{array}{l}0.47 \pm \\
0.018\end{array}$ & $-137.3 \%$ \\
\hline $\begin{array}{c}\text { Arginase } \\
\text { U /L }\end{array}$ & $\begin{array}{c}91.28 \pm \\
8.02\end{array}$ & $64.13 \%$ & $\begin{array}{c}254.5 \pm \\
21.3\end{array}$ & ----- & $\begin{array}{c}212.6 \pm \\
21.5\end{array}$ & $16.46 \%$ & $\begin{array}{c}229.7 \pm \\
9.6\end{array}$ & $9.74 \%$ & $\begin{array}{c}104.2 \pm \\
8.5\end{array}$ & $59.05 \%$ \\
\hline
\end{tabular}

$* \mathrm{p}<0.05=$ significant; $\mathrm{p}<0.01 * *=$ highly significant. 
Table (6): Effect of (Compound 4) on "MDA, NO, SOD, TAC and Arginase in plasma:

\begin{tabular}{|c|c|c|c|c|c|c|c|c|c|c|}
\hline \multirow[t]{2}{*}{ Variables } & \multicolumn{2}{|c|}{$\begin{array}{c}\text { Negative control group } \\
\text { (Gr.I) }\end{array}$} & \multicolumn{2}{|c|}{$\begin{array}{c}\text { Positive Control Group } \\
\text { (Gr. II) }\end{array}$} & \multicolumn{2}{|c|}{$\begin{array}{c}\text { Preventive Group } \\
\text { (Gr.III a) }\end{array}$} & \multicolumn{2}{|c|}{$\begin{array}{c}\text { Therapeutic Group } \\
\text { (Gr.III b) }\end{array}$} & \multicolumn{2}{|c|}{$\begin{array}{l}\text { +ve Drug } \\
\text { (Gr.III c) }\end{array}$} \\
\hline & $\begin{array}{l}\text { Mean } \pm \\
\text { SD. }\end{array}$ & \% Change & $\begin{array}{l}\text { Mean } \pm \\
\text { SD. }\end{array}$ & $\%$ Change & $\begin{array}{l}\text { Mean } \pm \\
\text { SD. }\end{array}$ & $\begin{array}{c}\% \\
\text { Change }\end{array}$ & $\begin{array}{l}\text { Mean } \pm \\
\text { SD. }\end{array}$ & $\begin{array}{c}\% \\
\text { Change }\end{array}$ & $\begin{array}{l}\text { Mean } \pm \\
\text { SD. }\end{array}$ & $\begin{array}{c}\% \\
\text { Change }\end{array}$ \\
\hline $\begin{array}{c}\text { MDA } \\
\mathrm{nmol} / \mathrm{ml}\end{array}$ & $11.6 \pm 0.37$ & $72.6 \%$ & $\begin{array}{c}42.74 \pm \\
1.89\end{array}$ & ----- & $\begin{array}{c}20.33 \pm \\
0.658\end{array}$ & $52.4 \%$ & $\begin{array}{c}26.28 \pm \\
2.51\end{array}$ & $36.69 \%$ & $\begin{array}{c}14.6 \pm \\
1.14\end{array}$ & $65.83 \%$ \\
\hline $\begin{array}{c}\text { NO } \\
\mu \mathrm{mol} / \mathrm{I}\end{array}$ & $21.4 \pm 2.13$ & $58.34 \%$ & $\begin{array}{c}51.38 \pm \\
3.9\end{array}$ & ----- & $\begin{array}{c}20.69 \pm \\
0.807\end{array}$ & $59.7 \%$ & $\begin{array}{l}25.29 \pm \\
2.38\end{array}$ & $50.77 \%$ & $\begin{array}{c}23.4 \pm \\
1.26\end{array}$ & $54.45 \%$ \\
\hline $\begin{array}{l}\text { SOD } \\
\text { U/mL }\end{array}$ & $203.8 \pm 3.87$ & $-106.3 \%$ & $\begin{array}{l}98.78 \pm \\
4.05\end{array}$ & ----- & $\begin{array}{c}391.71 \pm 2 \\
0.41\end{array}$ & $-296.5 \%$ & $\begin{array}{l}383.9 \pm \\
20.62\end{array}$ & $-288.6 \%$ & $\begin{array}{c}198.07 \pm \\
12.74\end{array}$ & $-100.4 \%$ \\
\hline $\begin{array}{l}\text { TAC } \\
\mathrm{mM} / \mathrm{L}\end{array}$ & $\begin{array}{l}0.391 \pm \\
0.059\end{array}$ & $-97.47 \%$ & $\begin{array}{c}0.198 \pm \\
0.041\end{array}$ & ----- & $\begin{array}{l}0.98 \pm \\
0.102\end{array}$ & $-394.9 \%$ & $\begin{array}{c}0.75 \pm \\
0.07\end{array}$ & $-278.7 \%$ & $\begin{array}{c}0.43 \\
\pm 0.024\end{array}$ & $-117.1 \%$ \\
\hline $\begin{array}{l}\text { Arginase } \\
\mathbf{U} / \mathbf{L}\end{array}$ & $91.28 \pm 8.02$ & $64.13 \%$ & $\begin{array}{l}254.5 \pm \\
21.3\end{array}$ & ----- & $\begin{array}{l}170.07 \pm 2 \\
\quad 6.7\end{array}$ & $33.7 \%$ & $\begin{array}{c}205.26 \pm \\
10.5\end{array}$ & $92.04 \%$ & $\begin{array}{l}100.5 \pm \\
9.5\end{array}$ & $60.51 \%$ \\
\hline
\end{tabular}

$* \mathrm{p}<0.05=$ significant $\mathrm{p}<0.01 * *=$ highly significant

Table (7): Effect of (Compound 5) On Anti-oxidants "MDA, NO, SOD, and TAC" in plasma

\begin{tabular}{|c|c|c|c|c|c|c|c|c|c|c|}
\hline \multirow[t]{2}{*}{ Variables } & \multicolumn{2}{|c|}{$\begin{array}{l}\text { Negative control } \\
\text { group (Gr.I) }\end{array}$} & \multicolumn{2}{|c|}{$\begin{array}{l}\text { Positive Control Group } \\
\text { (Gr. II) }\end{array}$} & \multicolumn{2}{|c|}{$\begin{array}{c}\text { Preventive Group } \\
\text { (Gr.III a) }\end{array}$} & \multicolumn{2}{|c|}{$\begin{array}{l}\text { Therapeutic Group } \\
\text { (Gr.III b) }\end{array}$} & \multicolumn{2}{|c|}{$\begin{array}{l}\text { +ve Drug } \\
\text { (Gr.III c) }\end{array}$} \\
\hline & $\begin{array}{l}\text { Mean } \pm \\
\text { SD. }\end{array}$ & $\begin{array}{c}\% \\
\text { Change }\end{array}$ & $\begin{array}{l}\text { Mean } \pm \\
\text { SD. }\end{array}$ & $\begin{array}{c}\% \\
\text { Change }\end{array}$ & $\begin{array}{c}\text { Mean } \pm \\
\text { SD. }\end{array}$ & $\begin{array}{c}\% \\
\text { Change }\end{array}$ & $\begin{array}{c}\text { Mean } \pm \\
\text { SD. }\end{array}$ & $\begin{array}{c}\% \\
\text { Change }\end{array}$ & $\begin{array}{l}\text { Mean } \pm \\
\text { SD. }\end{array}$ & $\%$ Change \\
\hline $\begin{array}{c}\text { MDA } \\
\mathrm{nmol} / \mathrm{ml}\end{array}$ & $\begin{array}{c}11.6 \\
\pm 0.37\end{array}$ & $72.6 \%$ & $\begin{array}{l}42.74 \pm 1 \\
\quad 89\end{array}$ & ----- & $\begin{array}{l}11.45 \pm \\
0.948\end{array}$ & $73.32 \%$ & $\begin{array}{c}15.88 \pm \\
1.349\end{array}$ & $63.03 \%$ & $\begin{array}{l}15.11 \pm \\
1.073\end{array}$ & $64.6 \%$ \\
\hline $\begin{array}{c}\text { NO } \\
\mu \mathrm{mol} / \mathrm{l}\end{array}$ & $\begin{array}{c}21.4 \\
\pm 2.13\end{array}$ & $58.34 \%$ & $\begin{array}{c}51.38 \pm 3 \\
9\end{array}$ & ----- & $\begin{array}{l}19.22 \pm \\
0.758\end{array}$ & $62.63 \%$ & $\begin{array}{l}21.38 \pm \\
1.22\end{array}$ & $58.38 \%$ & $\begin{array}{l}19.63 \pm \\
1.538\end{array}$ & $61.79 \%$ \\
\hline $\begin{array}{l}\text { SOD } \\
\text { U/mL }\end{array}$ & $\begin{array}{l}203.8 \\
\pm 3.87\end{array}$ & $-106.3 \%$ & $\begin{array}{l}98.78 \pm 4 \\
05\end{array}$ & ----- & $\begin{array}{l}577.7 \pm \\
34.95\end{array}$ & $-484.7 \%$ & $\begin{array}{l}485.15 \\
\pm 49.25\end{array}$ & $-391.1 \%$ & $\begin{array}{c}210.77 \pm \\
16.67\end{array}$ & $-113.3 \%$ \\
\hline $\begin{array}{l}\text { TAC } \\
\mathrm{mM} / \mathrm{L}\end{array}$ & $\begin{array}{c}0.391 \pm \\
0.059\end{array}$ & $-97.47 \%$ & $\begin{array}{c}0.198 \pm \\
0.041\end{array}$ & ----- & $\begin{array}{l}2.19 \pm \\
0.179\end{array}$ & $-960.6 \%$ & $\begin{array}{l}1.47 \pm \\
0.405\end{array}$ & $-642.4 \%$ & $\begin{array}{l}0.52 \pm \\
0.025\end{array}$ & $-162.6 \%$ \\
\hline $\begin{array}{c}\text { Arginase } \\
\mathbf{U} / \mathbf{L}\end{array}$ & $\begin{array}{l}91.28 \pm \\
8.02\end{array}$ & $64.13 \%$ & $\begin{array}{c}254.5 \pm 21 \\
.3\end{array}$ & ----- & $\begin{array}{l}141.9 \\
\pm 10.5\end{array}$ & $44.24 \%$ & $\begin{array}{l}150.9 \pm \\
9.6\end{array}$ & $40.7 \%$ & $86.17 \pm 12.8$ & $66.14 \%$ \\
\hline
\end{tabular}

$* \mathrm{p}<0.05=$ significant; $\mathrm{p}<0.01 * *=$ highly significant 